\title{
Furuncular myiasis
}

INSERM

\section{Source}

INSERM. (1999). Orphanet: an online rare disease and orphan drug data base. Furuncular myiasis. ORPHA:591

Furuncular myiasis in humans is caused by two species: the Cayor worm (larvae of the African tumbu fly Cordylobia anthropophaga) and the larvae of the human botfly (Dermatobia hominis). 